\title{
High Maize Density Alleviates the Inhibitory Effect of Soil Nitrogen on Intercropped Pea
}

\author{
Cai Zhao ${ }^{1,2,+}$, Zhilong Fan ${ }^{1,2,+}$, Jeffrey A. Coulter ${ }^{3} \mathbb{D}$, Wen Yin ${ }^{1,2}$, Falong $\mathrm{Hu}^{1,2}$, Aizhong $\mathrm{Yu}^{1,2}$, \\ Hong Fan ${ }^{1,2}$ and Qiang Chai ${ }^{1,2, *}$ \\ 1 Gansu Provincial Key Laboratory of Aridland Crop Science, Gansu Agricultural University, Lanzhou 730070, \\ China; zhaoc@gsau.edu.cn (C.Z.); fanzl@gsau.edu.cn (Z.F.); yinwen@gsau.edu.cn (W.Y.); \\ hufl@gsau.edu.cn (F.H.); yuaizh@gsau.edu.cn (A.Y.); fanh@gsau.edu.cn (H.F.) \\ 2 College of Agronomy, Gansu Agricultural University, Lanzhou 730070, China \\ 3 Department of Agronomy and Plant Genetics, University of Minnesota, St. Paul, Minneapolis, MN 55108, \\ USA; coult077@umn.edu \\ * Correspondence: chaiq@gsau.edu.cn; Tel.: +86-931-7631104 \\ + Cai Zhao and Zhilong Fan contributed equally to this work.
}

Received: 12 January 2020; Accepted: 4 February 2020; Published: 7 February 2020

\begin{abstract}
Nitrogen (N) fixation is essential in the development of sustainable agriculture, but nodulation of legumes is usually inhibited by $\mathrm{N}$ fertilization. In this study, we evaluated the increased density of intercropped maize (Zea mays L.) as a means to alleviate the inhibitory effect of soil mineral $\mathrm{N}$ on intercropped pea (Pisum sativum L.) and improve system performance. A field experiment was conducted in the Hexi Corridor region of northwestern China from 2012 to 2014 . The experiment consisted of monoculture pea, monoculture maize, and a pea/maize strip-intercropping system. Two levels of $\mathrm{N}$ fertilization were evaluated in both cropping systems during the co-growth period of intercropping, i.e., $0 \mathrm{~kg} \mathrm{~N} \mathrm{ha}^{-1}$ (N0) and $135 \mathrm{~kg} \mathrm{~N} \mathrm{ha}^{-1}$ (N1), and three maize densities were evaluated with both levels of $\mathrm{N}$ fertilization in the intercropping system, i.e., 45,000 plants ha $^{-1}$ (D1), 52,500 plants ha ${ }^{-1}$ (D2), and 60,000 plants ha ${ }^{-1}$ (D3). The application of $\mathrm{N}$ reduced the number of nodules of intercropped pea by $135 \%$ at $\mathrm{D} 1$ and by $9 \%$ at $\mathrm{D} 2$ compared to no application of $\mathrm{N}$, in all the years examined. The alleviation of the inhibitory effect of soil mineral $\mathrm{N}$ on the nodulation of intercropped pea $\left(C_{i s}\right)$ was calculated as the percentage increase in nodulation with intercropping relative to monoculture for a given level of $\mathrm{N}$ fertilization. With the application of $\mathrm{N}, C_{i s}$ was improved by increased intercropped maize density (D3 > D2 > D1) at all stages. The internal efficiency of nitrogen (IEN) of pea was improved with intercropping and, on average, was $19 \%$ and $12 \%$ greater at D3 than at D1 and D2, respectively. These results demonstrate that increased maize density can alleviate the inhibitory effect of soil $\mathrm{N}$ on the nodulation of pea and sustain the productivity of maize/pea intercropping while reducing $\mathrm{N}$ fertilizer requirements in arid regions.
\end{abstract}

Keywords: maize/pea intercropping; plant density; nitrogen use efficiency; root nodules

\section{Introduction}

Cereal/legume intercropping has been widely used for its advantages of farmland biodiversity [1], greater resource utilization rate and crop yield compared to monoculture [2,3], and biological nitrogen (N) fixation to reduce fertilization requirements [4,5]. With fertilizer use contributing to environmental degradation and decreased sustainability of cropping systems [6], cereal/legume intercropping has gained attention for its ability to improve nutrient use efficiency and decrease the dependence on fertilizer [7-9]. Research on cereal/legume intercropping has focused on enhancing the capacity and utilization of biological $\mathrm{N}$ fixation through the manipulation of $\mathrm{N}$ fertilizer management for 
legumes $[10,11]$. Intercropping with cereals can alleviate the inhibitory effect of soil mineral $\mathrm{N}$ on the nodulation of legumes [8,12], but knowledge of how this is regulated by agronomic measures is still limited.

Crop species and varieties [13], cropping pattern [4], $\mathrm{N}$ fertilizer management [14], and plant density [15] are vital in regulating the interrelation between intercropped cereals and legumes. The optimization of these factors can improve the synergistic effects of competition and recovery and enhance the coordination of $\mathrm{N}$ use between cereal and legume intercrops, thereby enhancing crop yield and resource use efficiency with cereal/legume intercropping [16]. The modification of $\mathrm{N}$ fertilizer management and intercropping pattern can alleviate the inhibitory effect of soil mineral $\mathrm{N}$ on the nodulation of legume intercrops [11,17], but the influence that plant density of the cereal intercrop might have on this effect has not been established.

To address these issues, the effect of maize (Zea mays L.) plant density on the nodulation of pea (Pisum sativum L.) was evaluated in a maize/pea strip-intercropping system. The primary objective was to investigate how maize plant density influences the inhibitory effect of soil mineral $\mathrm{N}$ on the nodulation of intercropped pea. We hypothesized that suitable maize plant density could facilitate pea nodulation and alleviate the inhibitory effect of soil mineral $\mathrm{N}$ on pea and that high maize density could enhance the ability to absorb soil mineral $\mathrm{N}$ in pea strips and improve the internal nitrogen efficiency of pea (IEN). To test these hypotheses, we measured (i) the nodulation of pea in monoculture and intercropping systems, (ii) the aboveground $\mathrm{N}$ accumulation of the two component intercrops, and (iii) the grain and biomass production of pea and maize in the two cropping systems.

\section{Materials and Methods}

\subsection{Experimental Site}

The field experiment was conducted between 2012 and 2014 at the Wuwei Oasis Agricultural Experimental Station $\left(37^{\circ} 30^{\prime} \mathrm{N}, 103^{\circ} 5^{\prime}\right.$ E) of Gansu Agricultural University, China. This site is located in the eastern of part of the Hexi Corridor of northwestern China, in the temperate arid zone of the Eurasian continent. The long-term (1960-2009) mean annual solar radiation is $5.67 \mathrm{KJ} \mathrm{m}^{-2}$, the annual sunshine duration is $>2945 \mathrm{~h}$, the mean annual air temperature is $7.2^{\circ} \mathrm{C}$ with accumulated air temperature above $0{ }^{\circ} \mathrm{C}>3513^{\circ} \mathrm{C}$ and above $10^{\circ} \mathrm{C}>2985^{\circ} \mathrm{C}$, and the mean frost-free period is 156 $\mathrm{d}$. The experimental site is representative of a typical agro-ecosystem of the region, with abundant light and heat for one crop per year but insufficient for two crops per year, making it particularly suitable for intercropping [18]. The mean annual precipitation is $155 \mathrm{~mm}$, occurring mainly between June and September, and the potential evaporation is $>2400 \mathrm{~mm}$. The sandy loam soil at the site is classified as an Aridisol (FAO/UNESCO 1988) with a $\mathrm{pH}$ of 7.8 and an average soil bulk density in the $0-110 \mathrm{~cm}$ layer of $1.44 \mathrm{~g} \mathrm{~cm}^{-3}$.

\subsection{Experimental Design and Crop Management}

The experiment utilized a split-plot arrangement of treatments in a randomized complete block design with three replications. The main plots had three cropping systems that included: (1) monoculture pea (P. sativum L. cv. MZ-1, a needle-leaf cultivar adapted to the local area) that was planted at a rate of $1,800,000$ plants $\mathrm{ha}^{-1}$; (2) monoculture maize (Z. mays L. cv. Xian-yu 335, a popular local hybrid) planted at three different densities, i.e., 73,600 plants ha ${ }^{-1}$ (D1), 85,900 plants ha $^{-1}$ (D2), and 98,200 plants ha ${ }^{-1}$ (D3); and (3) maize/pea strip-intercropping systems planted at three different maize densities, i.e., 45,000 plants ha ${ }^{-1}$ (D1), 52,500 plants ha ${ }^{-1}$ (D2), and 60,000 plants ha ${ }^{-1}$ (D3). Split plots were two levels of N fertilization, N0 $\left(0 \mathrm{~kg} \mathrm{ha}^{-1}\right)$ and N1 (135 kg ha-1) (Table 1), for a total of 42 experimental plots, each $8 \mathrm{~m}$ long $\times 5.7 \mathrm{~m}$ wide. Each plot was separated by a ridge that was $0.5 \mathrm{~m}$ wide and $0.3 \mathrm{~m}$ high to avoid movement of irrigation water between plots. 
Table 1. Description of experimental treatments, including the maize density and nitrogen $(\mathrm{N})$ fertilizer applied to pea at the co-growth stage.

\begin{tabular}{|c|c|c|c|c|c|c|}
\hline \multirow[b]{2}{*}{$\begin{array}{l}\text { Cropping } \\
\text { Pattern }\end{array}$} & \multirow[b]{2}{*}{$\begin{array}{c}\text { Maize Plant } \\
\text { Density } \\
\left(\text { Plant ha }{ }^{-1}\right)\end{array}$} & \multirow[b]{2}{*}{$\begin{array}{c}\text { Codes of } \\
\text { Treatments }\end{array}$} & \multicolumn{4}{|c|}{ N Application Rates (kg ha-1) } \\
\hline & & & Total N & $\begin{array}{c}\text { Base } \\
\text { Fertilizer }\end{array}$ & $\begin{array}{c}\text { Maize } \\
\text { Pre-tasseling }\end{array}$ & $\begin{array}{l}15 \mathrm{~d} \text { after } \\
\text { Maize } \\
\text { Flowering }\end{array}$ \\
\hline \multirow{2}{*}{$\begin{array}{c}\text { Monoculture } \\
\text { pea }(\mathrm{P})\end{array}$} & \multirow[t]{2}{*}{ - } & $\mathrm{PN}_{0}$ & 0 & 0 & 0 & 0 \\
\hline & & $\mathrm{PN}_{1}$ & 135 & 135 & 0 & 0 \\
\hline \multirow{6}{*}{$\begin{array}{l}\text { Monoculture } \\
\text { maize (M) }\end{array}$} & \multirow{2}{*}{ D1 $(73,600)$} & $\mathrm{MD}_{1} \mathrm{~N}_{0}$ & 0 & 0 & 0 & 0 \\
\hline & & $\mathrm{MD}_{1} \mathrm{~N}_{1}$ & 450 & 135 & 225 & 90 \\
\hline & \multirow{2}{*}{ D2 $(85,900)$} & $\mathrm{MD}_{2} \mathrm{~N}_{0}$ & 0 & 0 & 0 & 0 \\
\hline & & $\mathrm{MD}_{2} \mathrm{~N}_{1}$ & 450 & 135 & 225 & 90 \\
\hline & \multirow{2}{*}{ D3 $(98,200)$} & $\mathrm{MD}_{3} \mathrm{~N}_{0}$ & 0 & 0 & 0 & 0 \\
\hline & & $\mathrm{MD}_{3} \mathrm{~N}_{1}$ & 450 & 135 & 225 & 90 \\
\hline \multirow{6}{*}{$\begin{array}{c}\text { Maize/pea } \\
\text { intercropping } \\
(\mathrm{M} / \mathrm{P})\end{array}$} & \multirow{2}{*}{ D1 $(45,000)$} & $\mathrm{MD}_{1} / \mathrm{PN}_{0}$ & 0 & 0 & 0 & 0 \\
\hline & & $\mathrm{MD}_{1} / \mathrm{PN}_{1}$ & 450 & 135 & 225 & 90 \\
\hline & \multirow{2}{*}{ D2 $(52,500)$} & $\mathrm{MD}_{2} / \mathrm{PN}_{0}$ & 0 & 0 & 0 & 0 \\
\hline & & $\mathrm{MD}_{2} / \mathrm{PN}_{1}$ & 450 & 135 & 225 & 90 \\
\hline & \multirow{2}{*}{ D3 $(60,000)$} & $\mathrm{MD}_{3} / \mathrm{PN}_{0}$ & 0 & 0 & 0 & 0 \\
\hline & & $\mathrm{MD}_{3} / \mathrm{PN}_{1}$ & 450 & 135 & 225 & 90 \\
\hline
\end{tabular}

In the intercropping treatments, pea and maize were alternated in $190 \mathrm{~cm}$-wide strips. Pea strips were $80 \mathrm{~cm}$ wide and consisted of four rows spaced $20 \mathrm{~cm}$ apart, whereas maize strips were $110 \mathrm{~cm}$ wide and consisted of three rows spaced $40 \mathrm{~cm}$ apart (Figure 1). Maize occupied $58 \%$ of the plot area, and pea occupied the remaining $42 \%$. Maize strips were mulched with plastic film at planting, an innovative technology largely adopted in arid areas to boost maize productivity [19]. Maize density was manipulated by setting the intra-row spacing to $34 \mathrm{~cm}$ in D1, $29 \mathrm{~cm}$ in D2, and $24 \mathrm{~cm}$ in D3. Pea was sown at the same rate $\left(190 \mathrm{~kg} \mathrm{ha}^{-1}\right)$ in the monocrop and intercropping systems. Pea was planted by the beginning of April (on 1 April 2012, 28 March 2013, and 25 March 2014) and harvested by the third week of July. Maize was planted in late April (25 April 2012, 24 April 2013, and 22 April 2014) and harvested at the end of September.

Before planting, an $\mathrm{N}$ fertilizer was applied to maize and pea at rates of 0 and $135 \mathrm{~kg} \mathrm{~N} \mathrm{ha}^{-1}$, respectively (Table 1), and a phosphorus fertilizer was applied at $225 \mathrm{~kg} \mathrm{P}_{2} \mathrm{O}_{5} \mathrm{ha}^{-1}$ to both crops. For maize, the $\mathrm{N}$ fertilizer was also top-dressed after pea harvest at 0 and $315 \mathrm{~kg} \mathrm{~N} \mathrm{ha}^{-1}$. The fertilizer sources were urea (46-0-0 of N- $\mathrm{P}_{2} \mathrm{O}_{5}-\mathrm{K}_{2} \mathrm{O}$ ) and diammonium phosphate (18-46-0 of $\left.\mathrm{N}-\mathrm{P}_{2} \mathrm{O}_{5}-\mathrm{K}_{2} \mathrm{O}\right)$. Due to low precipitation at the experimental site, the maize/pea intercropping growing season was from 25 March to 25 September, and the natural precipitation was $160 \mathrm{~mm}$ in 2012, $174 \mathrm{~mm}$ in 2013, and $166 \mathrm{~mm}$ in 2014. Supplemental irrigation was applied using a plastic pipe system. A flow meter was installed at the discharging end of the pipe to record the irrigation volume entering each plot. Irrigation treatments were applied to all plots according to the maize growth stages, as follows: seeding $(90 \mathrm{~mm})$, jointing $(120 \mathrm{~mm})$, pre-heading $(120 \mathrm{~mm})$, silking $(120 \mathrm{~mm})$, and grain-filling $(90 \mathrm{~mm})$, for a total of $540 \mathrm{~mm}$. All plots received $120 \mathrm{~mm}$ of irrigation in the preceding fall just before soil freezing. 


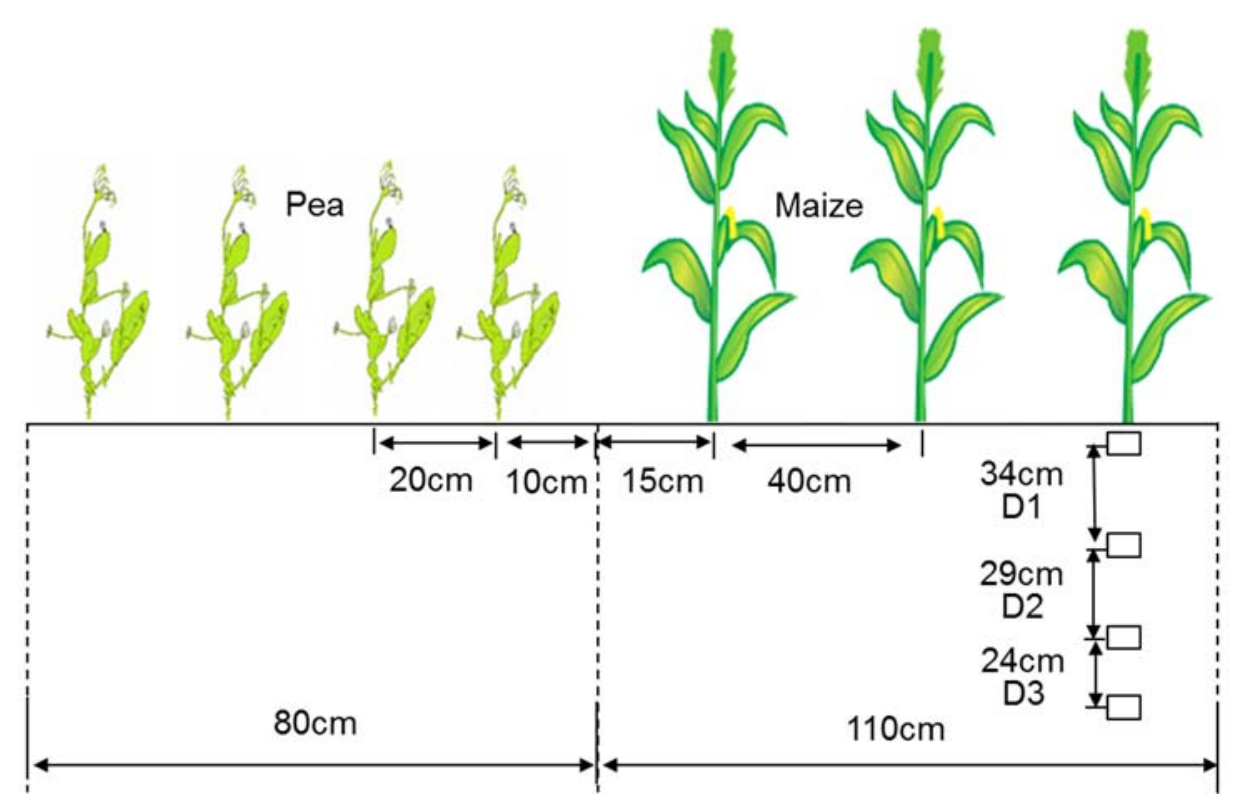

Figure 1. Spacing in maize/pea intercropping plots at the Wuwei Oasis Agriculture Experimental Station in the Hexi Corridor of northwestern China. Maize populations were 45,000 plants ha $^{-1}$ (D1), 52,500 plants ha ${ }^{-1}(\mathrm{D} 2)$, and 60,000 plants ha $^{-1}$ (D3).

\subsection{Plant Sampling and Nodule Collection}

Pea in the monocrop and intercropping systems was sampled at $15 \mathrm{~d}$ intervals, with the first sampling conducted at pea branching ( $25 \mathrm{~d}$ after emergence). At each sampling time, four adjacent rows of pea in the mono-crop or intercropping systems with row length of $30 \mathrm{~cm}$ were sampled to assess aboveground dry matter. All plant samples were oven-dried for $30 \mathrm{~min}$ at $105^{\circ} \mathrm{C}$ to desiccate the sample and then dried at $80^{\circ} \mathrm{C}$ to a constant weight. Maize and pea plant samples were milled after oven-drying prior to analysis of $\mathrm{N}$. $\mathrm{N}$ concentration in plant biomass was determined by a high-induction furnace $\mathrm{C}$ and $\mathrm{N}$ analyzer (Elementar vario MACRO cube, Frankfurt, Germany) after oven-drying and grinding to $1 \mathrm{~mm}$ [20]. Aboveground $\mathrm{N}$ accumulation was calculated as the product of $\mathrm{N}$ concentration and plant biomass. At crop physiological maturity, plots were harvested by hand, and the harvested grain was air-dried, cleaned, and weighed to determine grain yield.

Nodulation of pea was assessed at five stages of development: branching ( $25 \mathrm{~d}$ after emergence), initial flowering ( $40 \mathrm{~d}$ after emergence, $10 \%$ of plants flowering), full flowering ( $55 \mathrm{~d}$ after emergence), grain filling (70 d after emergence), and maturity ( $85 \mathrm{~d}$ after emergence). Roots in an area that was $50 \mathrm{~cm}$ deep $\times 30 \mathrm{~cm}$ wide $\times 30 \mathrm{~cm}$ long were excavated, rinsed with tap water, and assessed for nodulation, including nodule number, nodule biomass, and root biomass. All nodules were detached from the roots after gentle washing on a $2 \mathrm{~mm}$ sieve and then brought to the lab for further counting. Nodule samples were then sun-dried and weighed.

\subsection{Calculation and Statistical Analysis}

The relative change ratio $C_{i s}$ was used to assess alleviation of the inhibitory effect of $\mathrm{N}$ fertilization on nodulation of intercropped pea [11] and was calculated as:

$$
C_{i s}=\frac{Y_{i f n}-Y_{s f n}}{Y_{s f n}} \times 100
$$

where Yifn and Ysfn are nodule biomass or aboveground $\mathrm{N}$ accumulation of intercropped and monoculture pea for a given $\mathrm{N}$ rate, respectively. Intercropping enhanced nodulation of pea when $C_{i s}>0$. 
At physiological maturity, total aboveground biomass was determined as the sum of grain and straw yield $\left(\mathrm{kg} \mathrm{ha}^{-1}\right)$, grain and straw yield was multiplied by its $\mathrm{N}$ concentration to calculate plant $\mathrm{N}$ accumulation $\left(\mathrm{kg} \mathrm{ha}^{-1}\right)$. Internal efficiency of nitrogen use (IEN) was calculated as [21,22]:

$$
\mathrm{IEN}_{i}=\frac{Y_{i}}{\text { Nuptake }}
$$

where $Y i$ is the yield of crop $i\left(\mathrm{~kg}\right.$ harvestable product ha $\left.{ }^{-1}\right)$, and $N$ uptake is $\mathrm{N}$ uptake $(\mathrm{kg}$ total $\mathrm{N}$ uptake $\mathrm{ha}^{-1}$ ) by crop $i$.

\subsection{Statistical Analysis}

Data were analyzed at $p \leq 0.05$ using Statistical Analysis Software (SPSS software, version 17.0, IBM, USA). Analysis of variance was used to assess the significance of fixed effects, and means were compared using Fisher's protected LSD test. Cropping system and N fertilizer level were considered fixed effects, and replication was considered a random effect.

\section{Results}

\subsection{Nodulation of Pea}

Nodulation of pea was assessed at five key growth stages, i.e., branching ( $25 \mathrm{~d}$ after pea emergence), initial flowering ( $40 \mathrm{~d}$ after pea emergence), full flowering ( $55 \mathrm{~d}$ after pea emergence), grain filling (70 $\mathrm{d}$ after pea emergence), and maturity ( $85 \mathrm{~d}$ after pea emergence) (Figure 2 ). The number of nodules of pea increased with intercropping compared to monoculture $(p<0.05)$ (Figure 2). Over the years, the average nodule number of intercropped pea was $16 \%, 77 \%$, and $127 \%$ greater than that of monoculture pea for D1, D2, and D3, respectively, with no N applied, and 26\%, 64\%, and 116\% greater, respectively, with $\mathrm{N}$ application. At branching, initial flowering, full flowering, and grain-filling stages, there was a significant cropping system $\times \mathrm{N}$ fertilization interaction affecting pea nodulation $(p<0.05)$. For intercropped pea, which received $135 \mathrm{~kg} \mathrm{~N} \mathrm{ha}^{-1}$, the nodule number decreased by $19.69 \%$ (2012), 32.58\% (2013), and 25.90\% (2014), compared to the control with no $\mathrm{N}$ fertilizer. For the intercropped pea, the D3 intercropped maize density had the highest nodule number at initial flowering, full flowering, and grain-filling stages. Compared to D1 and D2, the nodule number of D3 with N application increased by $47.05 \%, 1.19 \%$ (2012), 100.19\%, 69.26\% (2013), 89.83\%, 35.08\% (2014), whereas this increase was of 68.99\%, 20.26\% (2012), 141.39\%, 38.76\% (2013), 102.79\%, 19.26\% (2014) when no N was applied. 

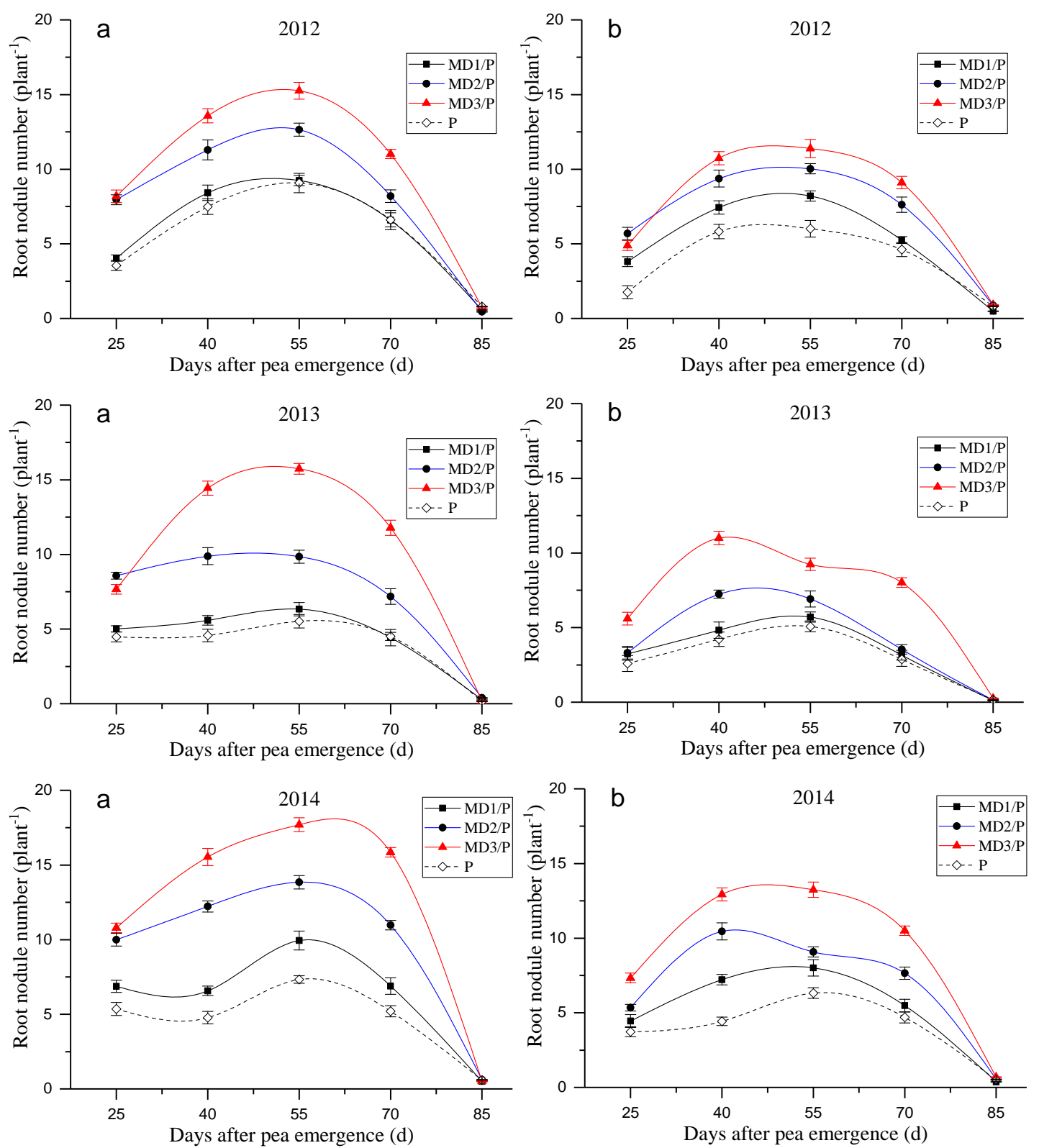

Figure 2. Root nodulation of pea from branching to maturity in pea monoculture and maize/pea intercropping in the Hexi Corridor of northwestern China from 2012 to 2014 . Monoculture (P) and intercropped pea (MD1/P, MD2/P, and MD3/P for different intercropped maize densities) were either unfertilized (a) or received $135 \mathrm{~kg} \mathrm{~N} \mathrm{ha}^{-1}$ at the co-growth period of pea and maize (b). Details of the maize/pea intercropping treatments are provided in Table 1. Data points are the mean with standard error bars $(n=3)$.

\subsection{Inhibitory Effect of Nitrogen on Intercropped Pea}

Alleviation of the inhibitory effect of soil mineral $\mathrm{N}$ on the nodulation of intercropped pea, as indicated by $C_{i s}$, was significantly affected by maize plant density (Table 2). With $\mathrm{N}$ application, $C_{i s}$ was improved by increasing intercropped maize density (D3 $>$ D2 $>$ D1) at all stages, especially at the full flowering stage of pea. Averaged across years, $C_{i s}$ for D3 was $63 \%$ and $160 \%$ greater than that for D2 and D1, respectively. In the absence of $\mathrm{N}$ fertilization, $C_{i s}$ was also enhanced by increasing intercropped maize density (D3 > D2 > D1). These results indicate that intercropping with maize alleviated the inhibitory effect of soil mineral $\mathrm{N}$ on nodulation of intercropped pea, and increasing intercropped maize density enhanced the alleviation. 
Table 2. Alleviation of the inhibitory effect of soil mineral $\mathrm{N}$ on nodulation of intercropped pea as affected by treatment, stage of pea phenological development, and year.

\begin{tabular}{|c|c|c|c|c|c|c|}
\hline Year & Treatment $^{a}$ & $\begin{array}{l}\text { Branching } \\
\text { (25 d) }\end{array}$ & $\begin{array}{c}\text { Initial } \\
\text { Flowering } \\
(40 \mathrm{~d})\end{array}$ & $\begin{array}{l}\text { Full Flowering } \\
\text { (55 d) }\end{array}$ & $\begin{array}{l}\text { Grain Filling } \\
\quad(70 \mathrm{~d})\end{array}$ & Maturity (85d) \\
\hline \multirow{6}{*}{2012} & MD1/PN0 & $24.38 \pm 1.75 \mathrm{e}^{\mathrm{b}}$ & $21.73 \pm 1.55 \mathrm{e}$ & $22.86 \pm 1.19 \mathrm{e}$ & $64.92 \pm 4.52 \mathrm{~b}$ & $18.35 \pm 1.97 c$ \\
\hline & MD2/PN0 & $46.19 \pm 1.79 c$ & $33.82 \pm 2.85 \mathrm{~d}$ & $55.24 \pm 2.74 \mathrm{c}$ & $69.62 \pm 1.12 b$ & $38.02 \pm 10.32 b$ \\
\hline & MD3/PN0 & $67.31 \pm 3.30 \mathrm{a}$ & $67.47 \pm 1.47 \mathrm{~b}$ & $78.43 \pm 2.62 b$ & $95.89 \pm 3.11 \mathrm{a}$ & $33.78 \pm 1.21 b$ \\
\hline & MD1/PN1 & $4.75 \pm 1.21 \mathrm{f}$ & $58.43 \pm 2.68 \mathrm{c}$ & $55.43 \pm 2.63 c$ & $33.81 \pm 1.52 \mathrm{~d}$ & $40.76 \pm 0.94 b$ \\
\hline & MD2/PN1 & $39.26 \pm 2.49 \mathrm{~d}$ & $55.88 \pm 2.17 \mathrm{c}$ & $48.29 \pm 1.62 \mathrm{~d}$ & $51.27 \pm 3.07 c$ & $35.99 \pm 1.76 b$ \\
\hline & MD3/PN1 & $59.71 \pm 1.94 b$ & $93.08 \pm 1.15 \mathrm{a}$ & $105.33 \pm 7.30 \mathrm{a}$ & $98.30 \pm 2.89 \mathrm{a}$ & $83.08 \pm 14.16 a$ \\
\hline \multirow{6}{*}{2013} & MD1/PN0 & $8.10 \pm 1.93 \mathrm{~d}$ & $33.91 \pm 2.70 b$ & $21.80 \pm 2.92 \mathrm{~d}$ & $28.69 \pm 2.00 \mathrm{e}$ & $66.45 \pm 4.15 \mathrm{ab}$ \\
\hline & MD2/PN0 & $46.44 \pm 1.53 \mathrm{~b}$ & $32.67 \pm 5.88 \mathrm{~b}$ & $64.22 \pm 2.14 c$ & $55.21 \pm 2.93 c$ & $79.85 \pm 9.85 a$ \\
\hline & MD3/PN0 & $49.55 \pm 2.95 b$ & $61.35 \pm 3.42 \mathrm{a}$ & $85.96 \pm 4.31 \mathrm{~b}$ & $123.22 \pm 8.89 b$ & $74.99 \pm 13.35 \mathrm{ab}$ \\
\hline & MD1/PN1 & $27.91 \pm 2.17 c$ & $14.19 \pm 3.29 \mathrm{~d}$ & $23.32 \pm 2.56 \mathrm{~d}$ & $43.88 \pm 1.89 \mathrm{~d}$ & $44.01 \pm 2.71 \mathrm{~cd}$ \\
\hline & MD2/PN1 & $31.96 \pm 2.37 c$ & $24.58 \pm 2.29 c$ & $83.03 \pm 4.81 \mathrm{~b}$ & $41.60 \pm 3.19 \mathrm{~d}$ & $65.19 \pm 7.14 b$ \\
\hline & MD3/PN1 & $77.84 \pm 7.09 \mathrm{a}$ & $52.13 \pm 4.16 \mathrm{a}$ & $109.70 \pm 10.75 \mathrm{a}$ & $162.93 \pm 6.21 \mathrm{a}$ & $36.82 \pm 3.56 \mathrm{~d}$ \\
\hline \multirow{6}{*}{2014} & MD1/PN0 & $21.92 \pm 3.08 \mathrm{e}$ & $31.88 \pm 1.73 \mathrm{~d}$ & $31.54 \pm 1.40 \mathrm{e}$ & $30.65 \pm 2.95 d$ & $28.20 \pm 3.71 b c$ \\
\hline & MD2/PN0 & $66.27 \pm 4.31 \mathrm{ab}$ & $78.94 \pm 4.72 \mathrm{~b}$ & $38.58 \pm 2.19 \mathrm{~d}$ & $42.15 \pm 1.16 \mathrm{c}$ & $32.65 \pm 2.52 \mathrm{ab}$ \\
\hline & MD3/PN0 & $68.28 \pm 2.18 a$ & $82.17 \pm 3.49 \mathrm{~b}$ & $71.97 \pm 2.00 \mathrm{~b}$ & $72.61 \pm 4.79 \mathrm{~b}$ & $32.70 \pm 1.51 \mathrm{ab}$ \\
\hline & MD1/PN1 & $38.71 \pm 1.77 \mathrm{~d}$ & $48.99 \pm 1.93 c$ & $36.49 \pm 2.53 \mathrm{de}$ & $29.11 \pm 2.71 \mathrm{~d}$ & $18.13 \pm 1.87 \mathrm{~d}$ \\
\hline & MD2/PN1 & $44.96 \pm 2.89 c$ & $56.58 \pm 1.12 c$ & $52.40 \pm 2.65 c$ & $42.26 \pm 3.66 c$ & $26.96 \pm 2.70 c$ \\
\hline & MD3/PN1 & $61.72 \pm 3.86 b$ & $109.42 \pm 8.37 \mathrm{a}$ & $84.50 \pm 2.62 \mathrm{a}$ & $93.71 \pm 5.49 \mathrm{a}$ & $34.06 \pm 2.84 \mathrm{a}$ \\
\hline & $\mathrm{SD}(0.05)$ & 2.03 & 2.39 & 2.70 & 2.66 & 4.26 \\
\hline \multicolumn{7}{|c|}{$\begin{array}{c}\text { Significance } \\
(P \text { value })\end{array}$} \\
\hline \multicolumn{2}{|c|}{$\begin{array}{l}\text { Intercropped maize } \\
\text { density (D) }\end{array}$} & 0.000 & 0.000 & 0.000 & 0.000 & 0.000 \\
\hline \multicolumn{2}{|c|}{$\begin{array}{l}\text { N application rates } \\
(\mathrm{N})\end{array}$} & 0.123 & 0.000 & 0.000 & 0.157 & 0.204 \\
\hline \multicolumn{2}{|r|}{$\mathrm{D} \times \mathrm{N}$} & 0.000 & 0.000 & 0.000 & 0.000 & 0.028 \\
\hline
\end{tabular}

${ }^{a} \mathrm{MD} 1 / \mathrm{PN} 0$, maize/pea intercropping with no $\mathrm{N}$ fertilizer for D1; MD2/PN0, maize/pea intercropping with no $\mathrm{N}$ fertilizer for D2; MD3/PN0, maize/pea intercropping with no $\mathrm{N}$ fertilizer for D3; MD1/PN1, maize/pea intercropping with $135 \mathrm{~kg}$ N fertilizer for D1; MD2/PN1, maize/pea intercropping with $135 \mathrm{~kg} \mathrm{~N}$ fertilizer for D2; MD3/PN1, maize/pea intercropping with $135 \mathrm{~kg} \mathrm{~N}$ fertilizer for D3. ${ }^{\mathrm{b}}$ Within a given year, means with different letters in the same column are significantly different at $p \leq 0.05$ according to Fisher's protected LSD test.

\subsection{Nitrogen Use Efficiency of Pea}

Year and $\mathrm{N}$ fertilization did not significantly affect IEN of pea $(p>0.05)$; however, there was a significant effect of the cropping system $(p<0.01)$ and of the interaction between cropping system and $\mathrm{N}$ fertilization $(p<0.01)$ (Figure 3). Intercropping improved IEN of pea by an average of $20 \%$ and $10 \%$ for N0 and N1, respectively. For intercropped pea, the IEN of pea with $135 \mathrm{~kg} \mathrm{~N} \mathrm{ha}^{-1}$, averaged across maize plant densities, decreased by $10.33 \%$ (2012), 16.71\% (2013), and 19.47\% (2014), compared to the control with no N. N use efficiency of intercropped pea was enhanced with increased maize plant density (D3 > D2 > D1). The IEN of pea at D3 was on average $6 \%$ and $9 \%$ greater than that at D2 and D1, respectively, with $\mathrm{N}$ application, whereas, with no $\mathrm{N}$ application, it was on average $8 \%$ and $12 \%$ greater, respectively. These results indicated that intercropping with high maize density improved the IEN of pea. 

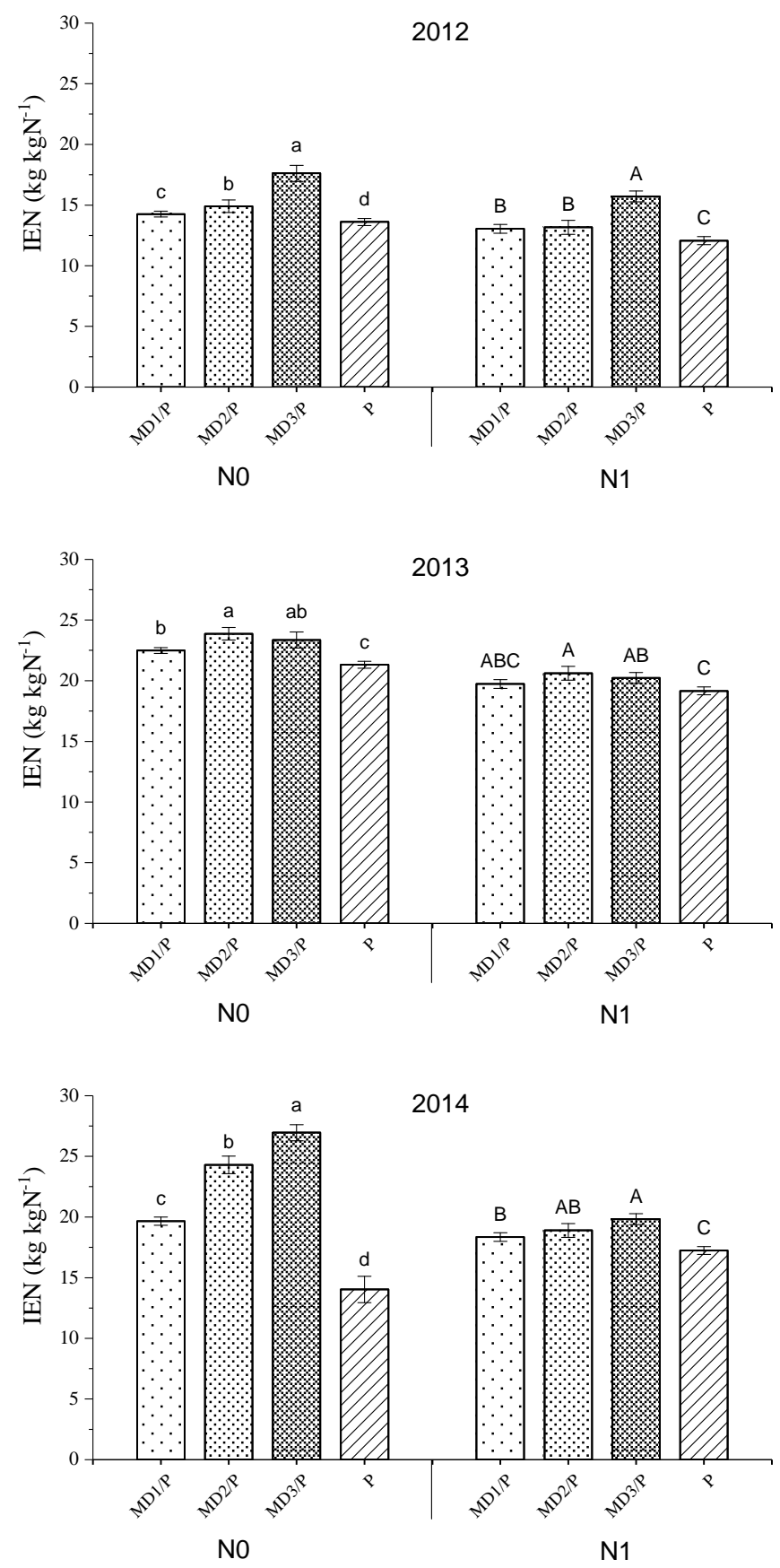

Figure 3. Internal efficiency of nitrogen (IEN) of pea for pea monoculture $(\mathrm{P})$ and maize/pea intercropping (MD1/P, MD2/P, and MD3/P for different intercropped maize densities) in the Hexi Corridor of northwestern China from 2012 to 2014. Crops were either unfertilized (N0) or received $135 \mathrm{~kg} \mathrm{~N} \mathrm{ha}^{-1}$ in the co-growth period of pea and maize (N1). Details of the maize/pea intercropping treatments are provided in Table 1 . Within a given level of fertilization, different letters indicate treatment means that are significantly different at $p \leq 0.05$ according to Fisher's protected LSD test. Error bars denote the standard error of the mean $(n=3)$.

\section{Discussion}

Compared to monoculture, intercropping with maize improved nodule number of pea and alleviated the effect of soil mineral $\mathrm{N}$ on the nodulation of pea. Our results are consistent with the findings of $\mathrm{Hu}$ et al. [14]. Intercropping with maize has also been shown to alleviate the inhibitory effect of $\mathrm{N}$ fertilization on nodulation and $\mathrm{N}_{2}$ fixation in faba bean (Vicia faba L.) [11] and to increase 
nodulation of common bean (Phaseolus vulgaris L.) [23]. The amount of nodulation and $\mathrm{N}$ fixed by the legume component in legume/cereal intercropping depends on several factors, including the species, density, management, and competitive ability of the component crop [24]. This study found that nodulation and alleviation of the effect of soil mineral $\mathrm{N}$ on nodulation of pea were enhanced by increasing the density of intercropped maize with and without $\mathrm{N}$ application. This is consistent with previous reports showing that low initial levels of soil $\mathrm{N}$ can suppress nodulation and $\mathrm{N}$ fixation in faba bean [25], cowpea (Vigna unguiculata L.), and soybean [Glycine max L. (Merr.)] [26]. Therefore, excessive $\mathrm{N}$ application or $\mathrm{N}$ deficiency can constrain legume nodulation. However, this can be improved by proper $\mathrm{N}$ application [27].

Intercropping with cereals can stimulate nodulation and $\mathrm{N}$ fixation of legumes possibly because they can utilize mineral $\mathrm{N}$ in the rhizosphere of legumes $[7,28]$. Our previous research showed that increased density of intercropped maize reduced soil mineral $\mathrm{N}$ during the pea/maize co-growth period [20]. Fujita et al. also reported that $\mathrm{N}$ transfer from soybean to intercropped sorghum (Sorghum bicolor L.) was improved by increased sorghum density [29]. Compared to monoculture, intercropping promotes the uptake and utilization of soil nutrients through root interaction, competition, and complementarity of component crops [5]. In this study, increased maize density improved the IEN of intercropped pea at both levels of $\mathrm{N}$ application. The IEN of pea ranged from 15.72 to $26.95 \mathrm{~kg} \mathrm{~kg}^{-1}$ for the highest intercropped maize density (D3), on average, over the three years of our analysis. Zhang et al. reported that IEN is closely associated with plant densities in intercropping and should be based on the crop yield in practical agricultural production [22]. Nonetheless, we are aware that nitrogen may have been lost by nitrogen leaching and nitrous oxide $\left(\mathrm{N}_{2} \mathrm{O}\right)$ and $\mathrm{N}_{2}$ emission from the system. Further evaluation of the effect of the lost nitrogen at multiple sites and in larger fields in the intercropping system is needed.

\section{Conclusions}

The cropping pattern plays an important role in alleviating the inhibitory effect of soil mineral $\mathrm{N}$ on nodulation of legumes. Using a quantitative analysis, the present study assessed the influence of component maize density on the alleviation of this inhibitory effect on intercropped pea. Overall, intercropping had a greater alleviatory effect than monoculture, which increased with increased maize density. Compared to the low intercropped maize density $\left(45,000\right.$ plants ha $\left.^{-1}\right)$, increasing maize density to 60,000 plants ha ${ }^{-1}$ enhanced the absorption capacity for soil mineral $\mathrm{N}$, as evidenced by the $9 \%$ and $12 \%$ improvements in the IEN of pea with and without $\mathrm{N}$ application, respectively. These results clearly demonstrate that a suitable component density is vital for maximizing the advantages of cereal/legume intercropping. An integrated approach such as the one described here is highly desirable for the development of sustainable agroecosystems.

Author Contributions: C.Z., Z.F., W.Y., F.H., A.Y., and H.F. conducted the experiments and collected field data; C.Z. and Z.F. performed the statistical analysis; C.Z. wrote the paper; J.A.C. and Q.C. reviewed, edited, and finalized the paper. All authors have read and agreed to the published version of the manuscript.

Funding: This research was funded by the National Natural Science Foundation of China (Grant No. 31860363).

Acknowledgments: This study was funded by the National Natural Science Foundation of China (31860363), the Natural Science Foundation of Gansu Province (17JR5RA157), the Research Program Sponsored by Gansu Provincial Key Laboratory of Aridland Crop Science, Gansu Agricultural University (GSCS-2016-05), and the China Agriculture Research System (CARS-22-G-12).

Conflicts of Interest: The authors declare no conflicts of interest.

\section{References}

1. Nourbakhsh, F.; Koocheki, A.; Mahallati, M.N. Investigation of biodiversity and some of the ecosystem services in the intercropping of corn, soybean and marshmallow. Int. J. Plant Prod. 2019, 13, 35-46. [CrossRef]

2. Chapagain, T.; Riseman, A. Barley-pea intercropping: Effects on land productivity, carbon and nitrogen transformations. Field Crops Res. 2014, 166, 18-25. [CrossRef] 
3. Mao, L.L.; Zhang, L.Z.; Li, W.Q.; van der Werf, W.; Sun, J.H.; Spiertz, H.; Li, L. Yield advantage and water saving in maize/pea intercrop. Field Crops Res. 2012, 138, 11-20. [CrossRef]

4. Banik, P. Evaluation of wheat (Triticum Aestivum) and legume intercropping under 1:1 and 2:1 row-replacement series system. J. Agron. Crop Sci. 2008, 176, 289-294. [CrossRef]

5. Li, L.; Zhang, F. Using competitive and facilitative interactions in intercropping systems enhances crop productivity and nutrient-use efficiency. Plant Soil 2003, 248, 305-312.

6. Martin-Guay, M.O.; Paquette, A.; Dupras, J.; Rivest, D. new green revolution: Sustainable intensification of agriculture by intercropping. Sci. Total Environ. 2018, 615, 767-772. [CrossRef]

7. Corre-Hellou, G.; Fustec, J.; Crozat, Y. Interspecific competition for soil N and its interaction with N2 fixation, leaf expansion and crop growth in pea-barley intercrops. Plant Soil 2006, 282, 195-208. [CrossRef]

8. Hauggaard-Nielsen, H.; Ambus, P.; Jensen, E.S. Interspecific competition, $\mathrm{N}$ use and interference with weeds in pea-barley intercropping. Field Crops Res. 2001, 70, 101-109. [CrossRef]

9. Hauggaard-Nielsen, H.; Gooding, M.; Ambus, P.; Corre-Hellou, G.; Crozat, Y.; Dahlmann, C.; Dibet, A.; Von Fragstein, P.; Pristeri, A.; Monti, M.; et al. Pea-barley intercropping for efficient symbiotic $\mathrm{N}_{2}$-fixation, soil $\mathrm{N}$ acquisition and use of other nutrients in european organic cropping systems. Field Crops Res. 2009, 113, 64-71. [CrossRef]

10. Chen, G.P.; Zhao, C.; Feng, F.X.; Yin, W. Effect of root interspecific interaction and irrigation level on nodulation characteristics of peas in a maize-pea intercropping system. Res. Agric. Mod. 2015, 36, 488-493.

11. Li, Y.Y.; Yu, C.B.; Cheng, X.; Li, C.J.; Sun, J.H.; Zhang, F.S.; Lambers, H.; Li, L. Intercropping alleviates the inhibitory effect of $\mathrm{N}$ fertilization on nodulation and symbiotic $\mathrm{N}_{2}$ fixation of faba bean. Plant Soil 2009, 323, 295-308. [CrossRef]

12. Chu, G.X.; Shen, Q.R.; Cao, J.L. Nitrogen fixation and $\mathrm{N}$ transfer from peanut to rice cultivated in aerobic soil in an intercropping system and its effect on soil N fertility. Plant Soil 2004, 263, 17-27. [CrossRef]

13. Baxevanos, D.; Tsialtas, I.T.; Vlachostergios, D.N.; Hadjigeorgiou, I.; Dordas, C.; Lithourgidis, A. Cultivar competitiveness in pea-oat intercrops under mediterranean conditions. Field Crops Res. 2017, 214, 94-103. [CrossRef]

14. Hu, F.; Zhao, C.; Feng, F.; Chai, Q.; Mu, Y.; Zhang, Y. Improving N management through intercropping alleviates the inhibitory effect of mineral $\mathrm{N}$ on nodulation in pea. Plant Soil 2017, 412, 235-251. [CrossRef]

15. Hauggaard-Nielsen, H.; Andersen, M.K.; Joernsgaard, B.; Jensen, E.S. Density and relative frequency effects on competitive interactions and resource use in pea-barley intercrops. Field Crops Res. 2006, 95, 256-267. [CrossRef]

16. Kermah, M.; Franke, A.C.; Adjei-Nsiah, S.; Ahiabor, B.D.; Abaidoo, R.C.; Giller, K.E. Maize-grain legume intercropping for enhanced resource use efficiency and crop productivity in the Guinea Savanna of Northern Ghana. Field Crops Res. 2017, 213, 38-50. [CrossRef]

17. Zhao, C.; Chai, Q.; Qiao, Y.Y.; Wang, J.K. Effect of cereal-legume spacing in intercropping system on alleviating 'N inhibition' in pea plants. Chin. J. Eco-Agricul. 2016, 24, 1169-1176.

18. Li, L.; Sun, J.; Zhang, F.; Li, X.; Yang, S.; Rengel, Z. Wheat/maize or wheat/soybean strip intercropping I. Yield advantage and interspecific interactions on nutrients. Field Crops Res. 2001, 71, 123-137. [CrossRef]

19. Gan, Y.; Siddique, K.H.; Turner, N.C.; Li, X.G.; Niu, J.Y.; Yang, C.; Liu, L.; Chai, Q. Ridge-furrow mulching systems-an innovative technique for boosting crop productivity in semiarid rain-fed environments. Adv. Agron. 2013, 118, 429-476.

20. Fan, Z.L.; Zhao, Y.H.; Chai, Q.; Zhao, C.; Yu, A.Z.; Coulter, J.A.; Gan, Y.T.; Cao, W.D. Synchrony of Nitrogen Supply and Crop Demand Are Driven via High Maize Density in Maize/Pea Strip Intercropping. Sci. Rep. 2019, 9, 1-4. [CrossRef]

21. Haefele, S.M.; Wopereis, M.C.; Ndiaye, M.K.; Barro, S.E.; Isselmou, M.O. Internal nutrient efficiencies, fertilizer recovery rates and indigenous soil nutrient supply of irrigated lowland rice in the Sahel and the Sudan Savanna regions of West Africa. Field Crops Res. 2003, 80, 19-32. [CrossRef]

22. Zhang, L.; Spiertz, J.H.J.; Zhang, S.; Li, B.; van der Werf, W. Nitrogen economy in relay intercropping systems of wheat and cotton. Plant Soil 2008, 303, 55-68. [CrossRef]

23. Cardoso, E.J.; Nogueira, M.A.; Ferraz, S.M. Biological $\mathrm{N}_{2}$ fixation and mineral $\mathrm{N}$ in common bean-maize intercropping or sole cropping in Southeastern Brazil. Exp. Agric. 2007, 43, 319-330. [CrossRef]

24. Ofori, F.; Stern, W.R. Cereal-legume intercropping systems. Adv. Agron. 1987, 41, 41-90. 
25. Xiao, Y.B.; Li, L.; Zhang, F.S. The interspecific nitrogen facilitation and the subsequent nitrogen transfer between the intercropped wheat and fababean. ZhongGuo Nongye Kexue 2005, 38, 965-973.

26. Eaglesham, A.R.; Hassouna, S.; Seegers, R. Fertilizer-N effects on $\mathrm{N}_{2}$ fixation by cowpea and soybean. Agron. J. 2010, 75, 61. [CrossRef]

27. Wang, S.Q.; Han, X.Z.; Qiao, Y.J.; Li, X.H. Soybea (Glycine Max L.) growth and nitrogen fixation as affected by different $\mathrm{N}$ supplying modes. Soybean Sci. 2009, 28, 859-862.

28. Yu, C.B.; Li, Y.Y.; Li, C.J.; Sun, J.H.; He, X.H.; Zhang, F.S.; Li, L. An improved nitrogen difference method for estimating biological nitrogen fixation in legume-based intercropping systems. Biol. Fertil. Soils 2010, 46, 227-235. [CrossRef]

29. Fujita, K.; Ofosu-Budu, K.G.; Ogata, S. Biological nitrogen fixation in mixed legume-cereal cropping systems. Plant Soil 1992, 141, 155-175. [CrossRef]

(C) 2020 by the authors. Licensee MDPI, Basel, Switzerland. This article is an open access article distributed under the terms and conditions of the Creative Commons Attribution (CC BY) license (http://creativecommons.org/licenses/by/4.0/). 